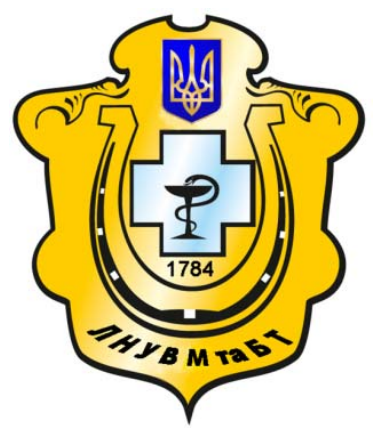

Науковий вісник Львівського національного університету ветеринарної медицини та біотехнологій імені С.3. Гжицького

Scientific Messenger of Lviv National University of Veterinary Medicine and Biotechnologies named after S.Z. Gzhytskyj

doi:10.15421/nvlvet6927

ISSN 2413-5550 print

ISSN 2518-1327 online

http://nvlvet.com.ua/

УДК 631.11(477:83)

\title{
Особливості функціонування аграрних підприємств Львівської області: проблеми і перспективи
}

\author{
Р.В. Сенів, І.Р.Оленич \\ RSeniv@ukr.net \\ Львівський національний університет ветеринарної медицини та біотехнологій імені С.3. Гжиџького, \\ вул. Пекарська, 50, м. Львів, 79010, Украӥна
}

В статті розглядається проблема виробництва молока в сільськогосподарських підприємствах Львівської області та напрямки ї̈ вирішення. Виробництво та реалізачія молока в сучасних кризових умовах функиіонування сільськогосподарських підприємств залишається одним з основних напрямів вирішення продовольчої проблеми. Основними виробниками молока в західному регіоні Украӥни є індивідуальні селянські господарства. На основі майна колишніх великих колективних сільськогосподарських підприємств сформовано дрібні самостійні виробничі структури. Внаслідок иього такі засоби виробництва як тваринницькі приміщення, силосні споруди опинилися у власності різних підприємств. В умовах низької прибутковості, а в багатьох випадках-збитковості, не можуть формуватись $і$ оновлюватись основні фонди. Індивідуальний сектор переважно не має товарної орієнтації. Більше того, формування продовольчого ринку в основному продукиією дрібнотоварних господарств є ознакою невисокого рівня економічного розвитку краӥни та значних диспропориій у народному господарстві. Для стабільного забезпечення молокопереробних підприємств якісною сировиною потрібно створювати спеціалізовані високорентабельні молочні ферми де технологія виробництва відповідала б сучасному рівневі й забезпечувала б отримання високоякісного $i$ дешевого молока. Для приватного сектору потрібно відновити знищену інфраструктуру заготівель молока.

Ключові слова: виробництво молока, сільськогосподарське підприємство, продуктивність, кооперація, організачія виробництва, маркетингове регулювання, аграрний сектор, інтеграція, закупівельні иіни, дотаиіï, рентабельність.

\section{Особенности функционирования аграрных предприятий Львовской области: проблемы и перспективы}

\author{
Р.В. Сенив, И.Р.Оленыч \\ RSeniv@ukr.net
}

\begin{abstract}
Львовский национальный университет ветеринарной медицины и биотехнологий имени С.3. Гжицкого, ул. Пекарская, 50, г. Львов, 79010, Украина
\end{abstract}

\begin{abstract}
В статье рассматривается проблема производства молока в сельскохозяйственных предприятиях Львовской области и способы ее решения. Производство и реализаиия молока в современных кризисных условиях функционирования сельскохозяйственных предприятий остается одним из основных направлений решения продовольственной проблемы. Основными производителями молока в западном регионе Украины есть индивидуальные хозяйства сельского населения. На основе
\end{abstract}

Citation:

Seniv, R., Olenych, I. (2016). Features of functioning the agricultural enterprises in Lviv region: problems and perspectives. Scientific Messenger LNUVMBT named after S.Z. Gzhytskyj, 18, 2(69), 136-140. 
имущества бывших крупных коллективных сельскохозяйственных предприятий сформирован мелкие самостоятельные производственные структуры. Вследствие этого такие средства производства как животноводческие помещения, силосные сооружения оказались в собственности различных предприятий. В условиях низкой доходности, а во многих случаях убыточности, не могут формироваться и обновляться основные фонды. Индивидуальныи сектор в основном не имеет товарной ориентации. Более того, формирование продовольственного рынка в основном продукцией мелкотоварных хозяйств является признаком невысокого уровня экономического развития страны и значительных диспропориий в народном хозяйстве. Для стабильного обеспечения молокоперерабатывающих предприятий качественным сырьем нужно создавать специализированные высокорентабельные молочные фермы где технология производства отвечала бы современному уровню и обеспечивала бы получение высококачественного и дешевого молока. Для частного сектора нужно восстановить уничтоженную инфраструктуру заготовок молока.

Ключевые слова: производство молока, сельскохозяйственное предприятие, производительность, кооперация, организация производства, маркетинговое регулирование, аграрный сектор, интеграция, закупочные цены, дотации, рентабельHocmb.

\title{
Features of functioning the agricultural enterprises in Lviv region: problems and perspectives
}

\author{
R. Seniv, I. Olenych \\ RSeniv@ukr.net

\begin{abstract}
Lviv national university of veterinary medicine and biotechnologies named after S. Gzhytskyj Pekarska Str., 50, Lviv, 79010, Ukraine
\end{abstract}

The article deals with the problem of milk production in farm enterprises of Lviv region and the directions to solve it.

Production and sale of milk in the current crisis functioning farm enterprises remains one of the main directions of solving the food problem. The main producers of milk in Western Ukraine is individual farms in rural population. In the process of reform the agricultural enterprises were disaggregated. On the basis of property of former large collective farms it has been formed small independent production structure. As a result, these means of production as livestock premises, silage buildings were owned by different companies. Milk production depends mainly on the structure of raw materials and raw material quality - factors, which form the competitive capacity of products of milk processing plants and determine their place on the consumptive market. First of all - a state of cow livestock as a raw material source. In recent years there has been deteriorated a condition in the dairy industry: it has decreased livestock of cows, decreased milk production, especially in the social sector, and, therefore, consumption of dairy products, and has decreased their quality. Added to this it is the insufficient level of milk production and procurement of milk both in farms and in public. By this time it has not been formed a clear relationship of parity between the production and processing of milk. Milk production in most enterprises is unprofitable. Resource potential is lost.

With such productivity and this herd is formed too high cost of milk. Requirements to improve dairy processing enterprises of purchase prices for milk above the cost can not be realized as dairy products will not be competitive.

In low profitability, and in many cases - the loss can not be formed and updated main fund. It should be expected reducing the supply of milk produced in farms. Individual sector has not mainly the commodity of orientation.

Moreover, the formation of the food market mainly production of small commercial economies is a sign of the low level of economic development and significant disproportions in the economy.

Key words: milk, agricultural enterprise, productivity, cooperation, organization of production, marketing regulation, agricultural sector, integration, prices, subsidies, profitability.

\section{Вступ}

Виробництво та реалізація молока в сучасних кризових умовах функціонування сільськогосподарських підприємств залишається одним з основних напрямів вирішення продовольчої проблеми. Основними виробниками молока в західному регіоні України $є$ індивідуальні господарства сільського населення. Частка молока, що виробляють у селянських господарствах, становить 75 - 80\% від загальних обсягів його виробництва, а у Львівській області вона сягає 95,5\%. У процесі здійснення реформ сільськогосподарські підприємства розкрупнені. На основі майна колишніх великих колективних сільськогосподарських підприємств сформовано дрібні самостійні виробничі структури. Внаслідок цього такі засоби виробництва як тваринницькі приміщення, силосні споруди опинилися у власності різних підприємств (табл. 1).

Метою дослідження в даній публікації $є$ обгрунтування системи організації аграрних підприємств й розробка рекомендацій з підвищення їх конкурентоздатності на засадах маркетингового регулювання (на прикладі виробників молока).

Для досягнення цієї мети поставлено такі наукові завдання:

- провести оцінку стану виробництва молока сільськогосподарськими підприємствами; обгрунтувати ефективність маркетингової діяльності сільськогосподарських підприємств; запропонувати шляхи розширення реалізації молочної продукції на засадах маркетингу та використання інноваційних технологій.

\section{Матеріал і методи досліджень}

Дослідження в даній публікації проведені із застосуванням діалектичного методу пізнання, відповідно до якого всі явища і процеси розглянуті у взаємозв'язку та розвитку. Для виконання поставлених завдань використано такі наукові методи: системного 
та економічного аналізу - для визначення обсягів виробництва молока; економіко-статистичний - для обгрунтування тенденцій розвитку системи маркетингу виробництві молока.

\section{Результати та їх обговорення}

Виробництво молока залежить, головним чином, від структури сировинної бази та якості сировини чинників, які формують конкурентоспроможність продукції молокопереробних підприємств і визнача- ють їх місце на споживчому ринку. Передусім - це стан поголів'я корів як сировинного джерела. Останніми роками спостерігається погіршення стану в молочній галузі: скоротилося поголів'я корів, зменшилися обсяги виробництва молока, особливо у суспільному секторі, а відтак, і споживання молочних продуктів, знизилася їх якість. До цього додався недостатній рівень організації виробництва та заготівель молока як у сільськогосподарських підприємствах, так і у населення.

Виробництво молока за категоріями господарств у Львівській області, тис. тонн

\begin{tabular}{|l|c|c|c|c|c|c|}
\hline Категорії господарств & 2010 & 2011 & 2012 & 2013 & 2014 & 2015 \\
\hline Усі категорії господарств & 656,2 & 629,6 & 620,7 & 619,4 & 601,0 & 571,2 \\
\hline $\begin{array}{l}\text { Сільськогосподарські підприємства/ } \\
\text { в т. ч. фермерські }\end{array}$ & $22,9 / 3,8$ & $23,1 / 4,6$ & $25,7 / 5,0$ & $26,4 / 4,8$ & $24,9 / 4,9$ & $25,6 / 4,7$ \\
\hline Господарства населення & 633,3 & 606,5 & 595,0 & 593,0 & 576,1 & 545,6 \\
\hline
\end{tabular}

До цього часу не сформовано чітких паритетних відносин між сферами виробництва і переробки молока. Виробництво молока у переважній більшості підприємств є збитковим. Втрачається ресурсний потенціал галузі. У Львівській області. продуктивність корів у сільськогосподарських підприємствах починаючи з 2010 року хоч і зростає, все ж у 2013 році вона становила лише 4087 кг. Поголів'я корів за 2010 - 2015 роки скоротилась 3161,7 до 129,7 тис голів. Не винятком є підприємства, де утримується 15 - 20 корів. У 1,7\% підприємств надій молока від 1 корови за рік становить більше 6000 кг, а у 30,2\% підприємств - до 3000 кг (табл.2).

При такій продуктивності і такому поголів’і формується надто висока собівартість виробництва молока. Вимоги щодо підвищення молокопереробними підприємствами закупівельних цін на молоко вище рівня собівартості не можуть бути реалізовані, оскільки молочні продукти не будуть конкурентоспроможними. Законом України «Про молоко і молочні продукти» від 24 червня 2004 року передбачено державне дотування до закупівельних цін, які повинні відшкодувати середньогалузеві нормативні витрати та забезпечувати мінімальний прибуток товаровиробнику. Однак фактично собівартість у підприємствах із незначним поголів'ям корів і надто низькою продуктивністю формується на рівні, що суттєво перевищує загальногалузеві нормативні затрати. Відповідно і на основі дотування не буде забезпечено прибуткове виробництво молока у всіх підприємствах.

В умовах значного зменшення великотоварних ферм і ускладнюється організація племінних робіт. Зменшилися можливості реального впливу обласного племоб'єднання та його дочірних підрозділів у районах на відбір корів з високими надоями молока. I, хоча, починаючи з 1997 року, обласною держадміністрацією була розроблена і затверджена Програма підтримки племінної справи, проте втілювати iii на практиці в умовах, коли понад 90\% молочного поголів'я ВРX зосереджено в особистих господарствах населення, дуже важко (Parkhomets, 2002).
Таблиия 2

Групування сільськогосподарських підприємств у Львіській області за рівнем продуктивності корів у 2013 році

\begin{tabular}{|c|c|c|}
\hline $\begin{array}{l}\text { Групи підприємств } \\
\text { за рівнем продуктив- } \\
\text { ності корів, кг }\end{array}$ & $\begin{array}{l}\text { Кількість } \\
\text { підпри- } \\
\text { ємств }\end{array}$ & $\begin{array}{l}\text { У відсотках } \\
\text { до загальної } \\
\text { кількості }\end{array}$ \\
\hline$\leq 1000$ & 9 & 7,8 \\
$1001-2000$ & 20 & 17,2 \\
$2001-3000$ & 35 & 30,2 \\
$3001-4000$ & 28 & 24,1 \\
$4001-5000$ & 14 & 12,1 \\
$5001-6000$ & 8 & 6,9 \\
$\geq 6000$ & 2 & 1,7 \\
\hline Разом & 116 & 100 \\
\hline
\end{tabular}

Не увінчались успіхами спроби забезпечення прибуткового виробництва молока шляхом прямого його збуту окремими сільськогосподарськими підприємствами, обминаючи сферу переробки. Прямий збут незначної кількості продукції $є$ дуже дорогим у розрахунку на іï одиницю. В умовах низької прибутковості, а в багатьох випадках - збитковості, не можуть формуватись і оновлюватись основні фонди. Слід очікувати скорочення пропозиції молока, виробленого у сільськогосподарських підприємствах. Індивідуальний сектор переважно не має товарної орієнтації. Більше того, формування продовольчого ринку в основному продукцією дрібнотоварних господарств $є$ ознакою невисокого рівня економічного розвитку країни та значних диспропорцій у народному господарстві.

Для стабільного забезпечення молокопереробних підприємств якісною сировиною треба створювати спеціалізовані високорентабельні молочні ферми де технологія виробництва відповідала б сучасному рівневі й забезпечувала б отримання високоякісного і дешевого молока. Для приватного сектору потрібно відновити знищену інфраструктуру заготівель молока а також зв'язки зі споживчою кооперацією.

Створити молочні ферми можна двома шляхами: будувати нові й реконструювати старі. Проте перший напрям є проблематичним бо вимагає великих інвестиційних вкладень. Більш реальним шляхом, що пот- 
ребує менших капітальних вкладень і часу, є створення сучасних молочних ферм на базі старих тваринницьких приміщень, які нині, через відсутність поголів'я худоби, не використовуються.

Досвід свідчить, що створення кожної конкретної ферми потребує технологічного i технікоекономічного обгрунтування. Завжди при прийнятті рішення про створення нової молочної ферми постають питання іï вартості і терміну окупності вкладень. Тому перш ніж прийняти таке рішення, щодо конкретної ферми проводять детальні технікоекономічні розрахунки.

Термін окупності затрат на створення молочної ферми шляхом реконструкції наявних тваринницьких приміщень залежить від таких основних чинників: продуктивності поголів'я, ціни на молоко та організації виробництва (рентабельності).

Молочні ферми можуть функціонувати 3 повним i неповним оборотом стада. Причому останні, як правило функціонують у країнах з розвинтою ринковою економікою, де запроваджено чітку спеціалізацію сільськогосподарського виробництва. В умовах України, де здійснюється процес становлення фермерства, більшість господарств змушена функціонувати 3 повним оборотом молочного стада, щоб своїми силами проводити ремонт і поповнення стада корів.

Щоб запобігти збитковості молочної ферми, потрібно збільшувати кількість поголів'я, а разом 3 тим i надої молока. Як свідчить практика та розрахунки фахівців, найбільша ефективність досягається у господарстві де утримується понад 100 корів. Це зумовлено насамперед спеціалізацією i концентрацією виробництва. Концентруються обмежені ресурси, які йдуть на розвиток галузі, сприяють поліпшенню використання основних виробничих засобів, зокрема сільськогосподарської техніки, фермерського устаткування, трудових ресурсів, а також раціонального витрачання матеріальних ресурсів (палива, кормів тощо) (Pidluzhna, 2002).

Через дефіцит сировини уже в даний час серед молокопереробних підприємств має місце гостра конкуренція за можливість заготівель молока у тих сільськогосподарських підприємствах, де виробляється значна кількість молока. Такі виробники можуть вибирати заготівельні організації на основі оголошеного тендера. Зрозуміло, що переваги будуть віддані перш за все тим організаціям, які запропонують більш високу ціну. Слід стимулювати формування тісних договірних відносин між підприємствами, що здійснюють виробництво молока і переробними підприємствами. Через дефіцит сировини потужності молокопереробних підприємств недовикористовуються. Збільшення обсягів заготівель призведе до зниження собівартості молочних продуктів. Корисний ефект від цього може бути розподілений між сільськогосподарськими і молокопереробними підприємствами. Згідно вище згаданого закону «Про молоко і молочні продукти» передбачається формування Узгоджувальних комісій однією 3 основних функцій якої буде погодження та подання рекомендацій щодо закупівельних цін на молоко, оптововідпускних цін на молочну продукцію та торгове- льних надбавок. На основі рішень Узгоджувальної комісії слід диференціювати закупівельні ціни, формувати надбавки до них у першу чергу на молоко тих сільськогосподарських підприємств у яких розроблено бізнес-плани та проекти і які забезпечують на практиці збільшення обсягів виробництва молока. Розмір надбавок до закупівельних цін слід пов'язувати із збільшенням обсягів виробництва у порівнянні з досягнутим рівнем. Таким чином можна впливати на створення фінансових умов i прискорення процесів формування порівняно великих товарних ферм.

Крім того стимулювання розвитку молочного скотарства необхідно здійснювати шляхом надання пільгових довгострокових кредитів, розвитку лізингових операцій для придбання технологічного устаткування для тваринництва, поліпшення умов одержання лізингу.

Важливою передумовою ефективного функціонування підприємств, що здійснюють виробництво молока $\epsilon$ інтегровані структури ринкового типу. Вказані структури повинні забезпечити скоординовану діяльність підприємств, що займаються племінною справою, вирощуванням ремонтного молодняка, виробництвом молока, його переробкою, транспортуванням та реалізацією молочної продукції.

\section{Висновки}

Перспективний етап розвитку виробництва продукції тваринництва в Україні передбачає кооперацію та інтеграцію селянських господарств на основі спеціалізації і концентрації виробництва певних видів продукції (молоко). Перевага функціонування сільскогосподарських підприємств в умовах їх кооперації доведена світовою практикою. Створені кооперативи мають сприяти запровадженню у сільськогосподарських підприємствах енерго- та ресурсозберігаючих технологій, підвищувати рівень інтенсифікації та матеріально-технічного постачання, спеціалізації та інтеграції виробництва і на цій основі удосконалення організації виробництва в окремих підприємствах.

Основні тенденції розвитку маркетингового управління: орієнтація на споживача, формування загальнокорпоративної довгострокової стратегії тощо. Маркетингова діяльність повинна забезпечити конкурентоспроможність, рентабельність підприємства, посилити його позиції на ринку тощо. У зв'язку з цим необхідно враховувати чинники впливу на процес управління маркетингом у сільськогосподарських підприємствах, зокрема рівень і якість використання маркетингового потенціалу, визначення ефективності маркетингу, розмір агропідприємств тощо.

Вважаємо за доцільне перетворення особистих селянських господарств на нові, ефективніші організаційно-правові структури через здійснення їх трансформації, об'єднання та інтеграції, що забезпечить підвищення рівня концентрації виробництва молока й дасть змогу збільшити рівень товарності, удосконалити форми реалізації молока, підвищити ефективність діяльності всіх учасників кооперації. 
Перспективи подальших досліджень. Майбутні дослідження будуть присвячені розробці моделей формування кластерів реалізації молочної продукції підприємствами регіонального рівня з використанням системи маркетингу, що дасть змогу впорядкувати стихійний характер виробництва молока в особистих селянських господарствах та сформувати сприятливі інституціональні передумови для нарощення інноваційно-інвестиційного потенціалу всього аграрного сектору

\section{Бібліографічні посилання}

Parkhomets, M.K. (2002). Optymizatsiia vyrobnychoi struktury fermerskykh hospodarstv molochnoho typu. Ekonomika APK. 1, 41-50 (in Ukrainian).

Pidluzhna, N.I. (2002). Rozvytok vyrobnytstva molokosyrovyny na Lvivshchyni. Ekonomika APK. 10, 59-63 (in Ukrainian).

Tvarynnytstvo Lvivshchyny: stat. zb. Lviv: Holovne upravlinnia statystyky u Lvivskii oblasti, 2015. 213 (in Ukrainian).

Стаття надійшла до редакиії 1.09.2016 